\title{
A NEW LICHENICOLOUS SPECIES OF MELASPILEA (MELASPILEACEAE, ARTHONIALES) FROM INDIA
}

\author{
P. SINGH ${ }^{1}$, Y. JosHI ${ }^{2}$ and K. P. SINGH ${ }^{1 *}$ \\ ${ }^{1}$ Botanical Survey of India, Central Regional Centre, 10-Chatham Lines, Allahabad-211 002 \\ Uttar Pradesh, India; *E-mail: krishna.p.singh@gmail.com \\ ${ }^{2}$ Lichenology laboratory, Department of Botany, S. S. J. Campus, Kumaun University \\ Almora-263 601, Uttarakhand, India
}

(Received 9 September, 2016; Accepted 5 April, 2017)

\begin{abstract}
A new lichenicolous fungus Melaspilea nitidochapsae colonising on the thallus of Nitidochapsa leprieurii (Mont.) Parnmen, Lücking et Lumbsch is described from India. The new species differs from other known species colonising lichen family Graphidaceae by having completely carbonised exciple, hyaline to pale brown transversely 1-septate ascospores and a different host.
\end{abstract}

Key words: Andaman and Nicobar Islands, lichenicolous fungus, Melaspilea

\section{INTRODUCTION}

The ascomycete genus Melaspilea Nyl. (Melaspileaceae W. Watson) characterised by arthonioid or opegraphoid ascomata, carbonised exciple consisting of several cell layers and hyaline to pale brown, transversely 1-septate ascospores (Perlmutter et al. 2015) is represented by about 70 species (Flakus et al. 2014, Joseph and Sinha 2015, Kalb et al. 2012, Kirk et al. 2008, Zhurbenko and Zhdanov 2013) across the world. Majority of its species are lichenised except twelve, viz. M. amarkantakensis S. Joseph et G. P. Sinha on Pertusaria sp., M. cupularis Müll. Arg. on Pyrenula sp., M. diplasiospora (Nyl.) Müll. Arg. on Graphis elegans, M. epigena Müll. Arg. on Reimnitzia santensis, M. epigraphella (Nyl.) Müll. Arg. on Acanthothecis consocians, M. galligena Zhurb. et I. Zhdanov on Pertusaria sp., M. insitiva Stirt. on Pertusaria leioplaca, M. lakae Brackel et Kalb on Sarcographa labyrinthica, M. leciographoides Vouaux on Verrucaria sp., M. lentiginosa (Lyell ex Leight.) Müll. Arg. on Phaeographis dendritica, M. tribuloides (Tuck.) Müll. Arg. on Anthracothecium sp. and Pyrenula sp., and M. tucumana 
Flakus, Etayo et Kukwa on Pertusaria sp., which are lichenicolous (Clauzade et al. 1989, Ertz and Diederich 2015, Flakus et al. 2014, Joseph and Sinha 2015, Kalb et al. 2012, Zhurbenko and Zhdanov 2013).

Neither Melaspilea nor any other lichenicolous fungi has hitherto been reported on Nitidochapsa leprieurii. Hence, our fungus is clearly distinct from all other known lichenicolous Melaspilea species and thus, deserves to be described as new species, which is dealt below.

\section{MATERIALS AND METHODS}

The specimen collected from Andaman and Nicobar Islands, deposited in BSA Herbarium was examined morphologically, anatomically and chemically. Morphological characters of reproductive structures and their colour, size and shapes were examined under a stereo microscope (Nikon SMZ-1500). Thin hand-cut sections of ascomata were mounted in water and $\mathrm{KOH}$ and examined under a compound microscope (Nikon Eclipse 50i). All anatomical measurements were made in water mounts. Ascomata and ascospores were stained with Lugol's solution to check the amyloid reaction.

\section{RESULTS AND DISCUSSION}

Melaspilea nitidochapsae Pushpi Singh, Y. Joshi et Kr. P. Singh, spec. nova (Fig. 1A-C)

MycoBank no.: MB 820798

Similar to Melaspilea epigraphella, but differs by its lichenicolous habit on the thallus of Nitidochapsa leprieurii and completely carbonised exciple.

Type: India. Andaman and Nicobar Islands, South Andaman Island, Motor Vhanji, Dhani-Khari Dam forest area, alt. $24 \mathrm{~m}, 11^{\circ} 33.738^{\prime} \mathrm{N}$ and $92^{\circ} 40.435^{\prime} \mathrm{E}$, on thallus of Nitidochapsa leprieurii, coll.: Singh, K. P. (9381B), 04 Feb. 2014 (holotype: BSA).

Ascomata lichenicolous on the thallus of Nitidochapsa leprieurii, black, lirelliform, solitary, scattered, very short, simple, prominent to sessile, 0.18 $0.30 \mathrm{~mm}$ long, 100-110 $\mu \mathrm{m}$ wide and 70-85 $\mu \mathrm{m}$ high; disc concealed to slitlike, epruinose (Fig. 1A). Exciple carbonaceous, continuous below the hypothecium, laterally 15-30 $\mu \mathrm{m}$ thick, basally 25-30 $\mu \mathrm{m}$ thick, K- (Fig. 1B). Epihymenium brownish, ca $8 \mu \mathrm{m}$ thick, $\mathrm{K}-$. Hymenium hyaline, thin, not inspersed with oil droplets, $40-45 \mu \mathrm{m}$ high, $\mathrm{K}-$, I+ pale blue, KI+ blue. Hypothecium hyaline to brown, $10-15 \mu \mathrm{m}$ thick, $\mathrm{K}-$, I+ red. Paraphyses unbranched to sparsely branched, 2.0-2.2 $\mu \mathrm{m}$ thick; apices indistinctly swollen, up to $3 \mu \mathrm{m}$ 
thick. Asci 6-8-spored (Fig. 1C), subclavate, 37-41 × 10-12 $\mu \mathrm{m}$. Ascospores hyaline, becoming brown when mature, ellipsoid to oblong, 1-septate, sole-
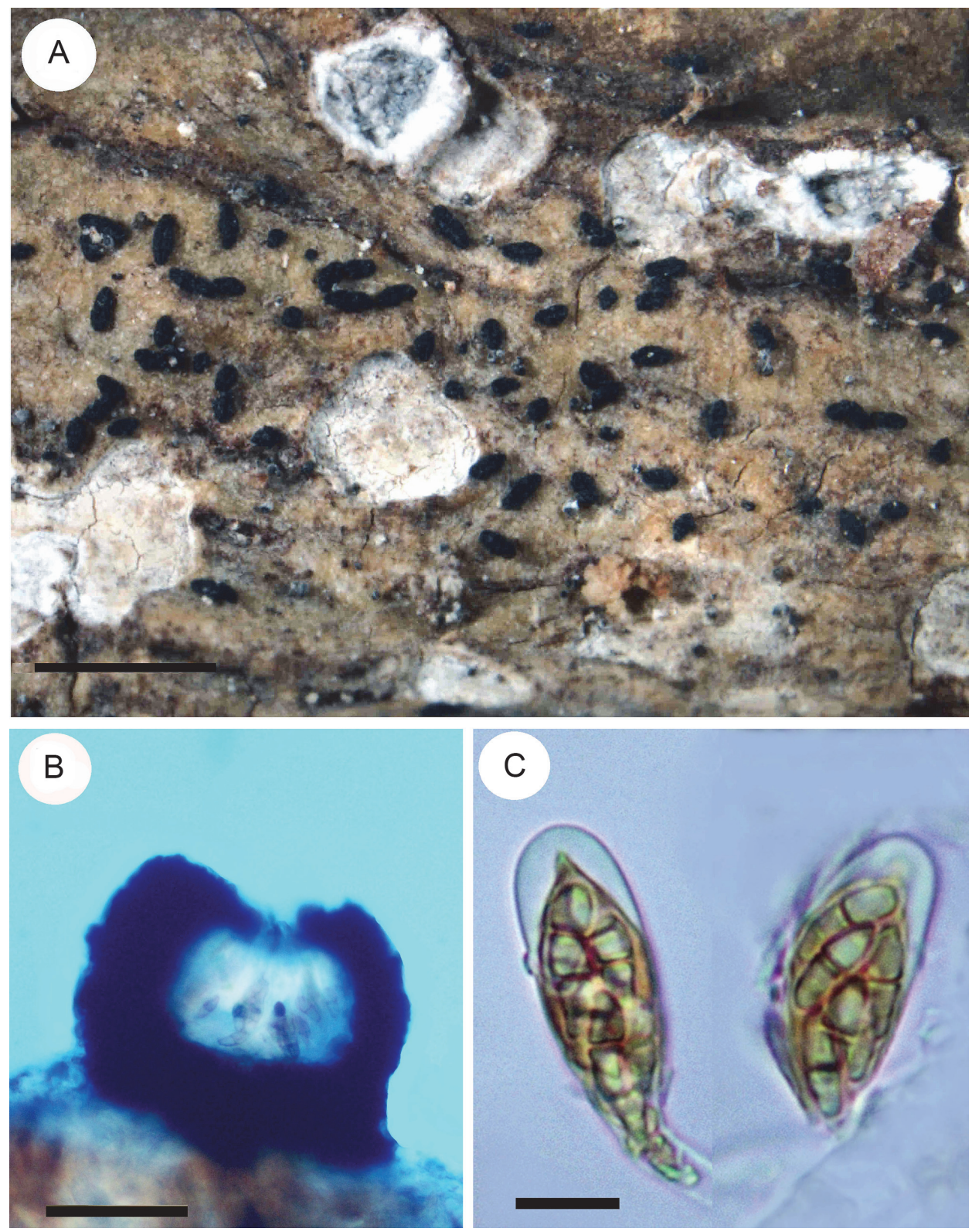

Fig. 1. Melaspilea nitidochapsae (holotype). A = ascomata of M. nitidochapsae on the thallus of Nitidochapsa leprieurii; $\mathrm{B}=$ cross section through an ascoma; $\mathrm{C}=$ asci with ascospores. Scale bars: $\mathrm{A}=1 \mathrm{~mm} ; \mathrm{B}=100 \mu \mathrm{m} ; \mathrm{C}=10 \mu \mathrm{m}$ 
shaped, slightly constricted at the septum, 9.5-11.5 × 3-4 $\mu \mathrm{m}$; cells as long as wide, I-. Pycnidia not known.

Distribution and habitat: The new species is so far known only from South Andaman Island, where it is growing in shady open places at DhaniKhari Dam tropical forest area on the thallus of Nitidochapsa leprieurii.

Etymology: The species epithet refers to the host name, i.e. lichenised fungus Nitidochapsa leprieurii (Mont.) A. Frisch.

Remarks: As mentioned earlier, so far 5 species of Melaspilea have been reported on members of Graphidaceae. The new taxon also growing on thelotremoid Graphidaceae taxa, i.e. Nitidochapsa leprieurii is well characterised by very short, prominent to sessile lirelliform ascomata having carbonised exciple, which is continuous below the hypothecium and 6-8-spored asci with brown, transversely 1-septate, 9.5-11.5 $\mu \mathrm{m}$ long ascospores. In general appearance and ascospore characters, it closely resembles Melaspilea epigraphella (lectotype: Nova Caledonia, Lifu, Loyalty insular, 1864, C. Thiébaut, s.n. H-Nyl-6217; bar code-9507757!), which differs in having laterally carbonised exciple that is absent below the hypothecium and a different host, viz. Acanthothecis consocians. It somewhat also resembles M. epigena, which has exposed disc and 5.5-7 $\mu \mathrm{m}$ broad ascospores and is lichenicolous on Reimnitzia santensis (Perlmutter et al. 2015). Melaspilea amarkantakensis and M. insitiva two other known species of this genus from India (Joshi et al. 2016) need not to be confused with this taxon as they use to colonise species of Pertusaria and have larger ascospores. The genus should not be confused with Opegrapha Ach., which has mostly hyaline, transversely more than 1-septate ascospores and branched and anastomosing paraphysoids.

Acknowledgements - The authors are thankful to Director, Botanical Survey of India, Kolkata for encouragement and to Head of Office, Botanical Survey of India, Central Regional Centre, Allahabad for facilities. Two of the authors (PS and YJ) are thankful to the authorities of Botanical Survey of India and GBPNIHESD (GBPI/IERP/16-17/175), for financial assistance respectively. The authors would like to thank Prof. S. Stenroos, Curators of herbarium at $\mathrm{H}$, Helsinki for loan of type specimen.

\section{REFERENCES}

Clauzade, G., Diederich, P. and Roux, C. (1989): Nelikenigintaj fungoj likenlogaj, ilustrita determinlibro. - Bull. Soc. Linn. Provence 1: 1-142.

Ertz, D. and Diederich, P. (2015): Dismantling Melaspileaceae: a first phylogenetic study of Buelliella, Hemigrapha, Karschia, Labrocarpon and Melaspilea. - Fungal Diversity 71(1): 141-164. https://doi.org/10.1007/s13225-015-0321-1 
Flakus, A., Etayo, J. and Kukwa, M. (2014): Melaspilea tucumana, a new gall-forming lichenicolous fungus from the tropical Andes in Bolivia. - Lichenologist 46(5): 657-662. https://doi.org/10.1017/s0024282914000188

Joseph, S. and Sinha, G. P. (2015): The lichenicolous species of Melaspilea (Melaspileaceae) in India. - Taiwania 60(1): 18-22.

Joshi, Y., Falswal, A., Tripathi, M., Upadhyay, S., Bisht, A., Chandra, K., Bajpai, R. and Upreti, D. K. (2016): One hundred and five species of lichenicolous biota from India: an updated checklist for the country. - Mycosphere 7(3): 368-394.

Kalb, K., Buaruang, K., Mongkolsuk, P. and Boonpragob, K. (2012): New or otherwise interesting lichens. VI, including a lichenicolous fungus. - Phytotaxa 42: 35-47. https:// doi.org/10.11646/phytotaxa.42.1.5

Kirk, P. M., Cannon, P. F., Minter, D. W. and Stalpers, J. A. (2008): Ainsworth E Bisby's dictionary of the fungi. 10th edition. - CAB. International Publishing, Wallingford, UK, $771 \mathrm{pp}$.

Perlmutter, G. B., Tucker, S. C., Rivas Plata, E., Clerc, P. and Lücking, R. (2015): Melaspilea demissa (Tuck.) Zahlbr. (lichenized Ascomycota) in eastern North America with a key to North American species of Melaspilea s. lat. - Lichenologist 47(3): 167-182. https://doi.org/10.1017/s0024282915000080

Zhurbenko, M. P. and Zhdanov, I. S. (2013): Melaspilea galligena sp. nov. and some other lichenicolous fungi from Russia. - Folia Cryptog. Eston. 50: 89-99. https://doi. org/10.12697/fce.2013.50.12 